
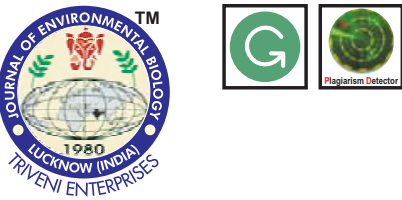

\title{
Long term survival and growth performance of selected seedling types in Cedar (Cedrus Iibani) afforestation in Turkey
}

Authors Info

N. Erkan* and A.C. Aydin

Forest Management and Yield Department, Southwest Anatolian Forest Research Institute, Sedir Mahallesi, Vatan Bulvari, 712 Sokak, Antalya-07010, Turkey

${ }^{*}$ Corresponding Author Email : nesaterkan@yahoo.com

Key words

Afforestation

Cedar forest

Seedling type

Survival rate

Publication Info

Paper received : 29.07 .2016

Revised received : 05.12.2016

Re-revised received : 31.01 .2017

Accepted : 09.03.2017

\section{Abstract}

Aim: Three different seedling types that are bare rooted, ENSO and polyethylene containerized seedlings are mainly used for Cedar afforestation in Turkey, however research on long-term field performance of these seedling types is meagre. The present study aims at comparing the survival and growth rate in order to determine the best seedling types for afforestation and also exploring their economic value at different sites.

Methodology: The study was carried out at two different experimental sites in Burdur-Bucak-Urkutlu and Antalya-Korkuteli-Yelten. A randomized block design with six blocks and three seedling types was applied at each site. One-year-old seedlings were planted within the sites and observed for 13 years. Data collected in the last seven years were used for statistical analyses. Analysis of variance was performed at each site and different seedling types were compared through Duncan's multiple range tests.

Results: Results showed that there were significant differences between the seedling types at $P<0.05$ level for survival and $P<0.01$ level for growth rate. At both sites, the containerized seedlings had higher survival rates than the other seedling types. At Yelten, the containerized seedlings had $39 \%$ and $28 \%$ higher growth rates than ENSO and bare rooted seedlings. These rates were $21 \%$ and $17 \%$ at Urkutlu site, respectively. Afforestation investment costs for the containerized seedlings were also $23.9 \%$ and $15.4 \%$ higher than for the bare rooted and ENSO stock at Yelten and $27.6 \%$ and $20.6 \%$, respectively, in Urkutlu.

Interpretation: The results showed that containerized seedlings can be suggested for afforestation at similar sites considering their higher growth performance, even if the costs are higher than those of other types.

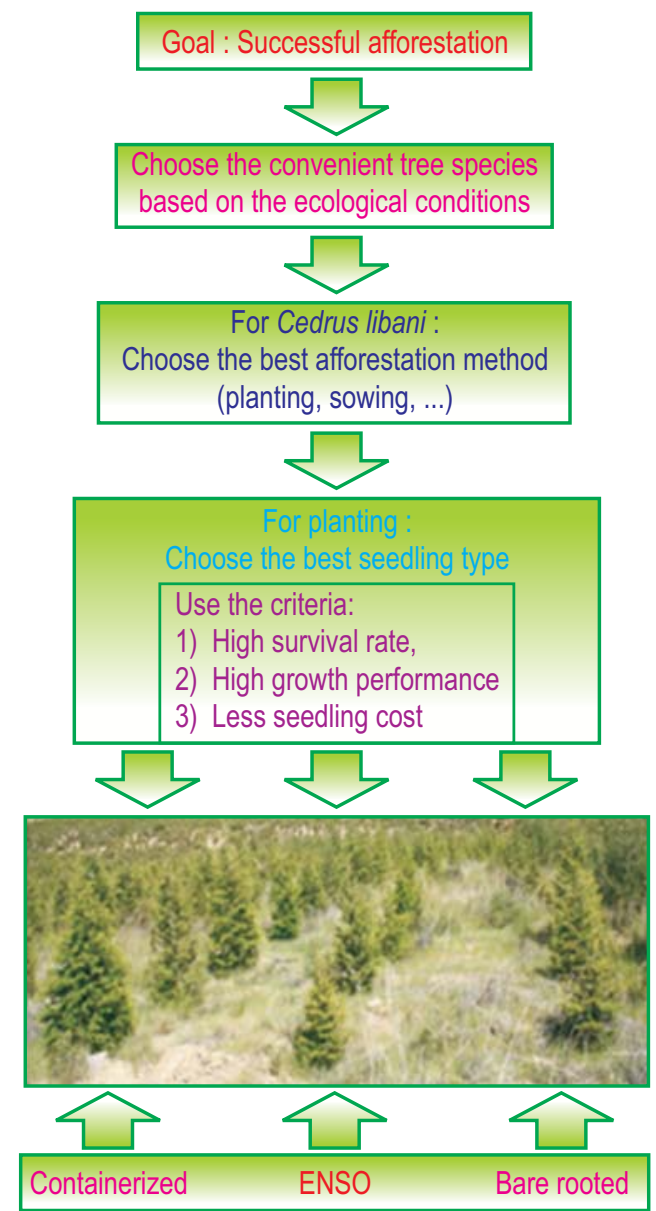




\section{Introduction}

Cedar (Cedrus libani A. Rich.) is distributed naturally in Anatolia, Lebanon and Syria. It has been exploited throughout the history for its valuable wood, and today it exists only in limited areas (Boydak and Calikoglu, 2008; Yaltirik and Akkemik, 2011). Its widest distribution is in Turkey with 463,000 ha of pure and mixed stands, which accounts only $2.1 \%$ of Turkey's total forest area (GDF, 2016). Cedar is commonly used for afforestation outside its natural distribution range not only in Turkey but also in Italy, Iran and Bulgaria especially in areas with poor ecological conditions due to its tolerance to water scarcity and high adaptation ability (Boydak et al., 1990; Erkan, 2006). However, its survival and growth rate might be low outside its natural distribution areas, especially with low annual precipitation and long dry summer season. Therefore, in such arid or semiarid areas, some additional precautions such as deep soil cultivation, selection of suitable seed provenances and better seedling material should be taken in order to increase the success of afforestation.

The success of afforestation depends on seedling type to some extent. Indeed, properly selected seedling types can enhance afforestation success considerably through increased survival and growth rate after out planting (Pinto et al., 2011). Barerooted and containerized seedlings grown in ENSO pot trays or polyethylene bags are the common seedling types used in Turkish forestry. However, there are conflicting observations about the field performance of these seedling types after establishment. Some of the scientists suggest containerized seedlings which perform better at most of the sites, but not ENSO type; while the others recommend bare rooted seedlings. Therefore, there is a need for new applied research studies to resolve the issues related to the performances of the seedling types in Turkish afforestation (Hizal et al., 2006; Kucukkaya, 2010).

Newly planted seedlings can survive at reforested site only if they have access to available soil water to meet their atmospheric demand of water. The ability of a seedling to take up water is affected by its root system, root-soil contact and root hydraulic conductivity. Newly planted seedlings have restricted root placements, low root system permeability and poor root-soil contact, which can limit water uptake from the soil (Burdett, 1990; Grossnickle, 2005). Root-soil contact is also related to the seedling type. Bare rooted and containerized seedlings have different root systems, therefore, their contact with the surrounding soil also varies. For that reason, under stressful conditions such as dryland areas, containerized seedlings have more advantages than bare rooted seedlings (Barnett and McGilvray, 1993).

Several observations and research studies have been performed on the initial survival rate of the seedling types of other conifers (TSF, 2015), however, there is no satisfactory information about the long-term survival and growth rate of cedar afforestation. Seedling type affects not only the field performance of the planted seedlings but also the establishment costs of afforestation. The price of seedlings, planting and seedling transfer costs can vary considerably depending on the seedling type. Therefore, cost-benefit should also be taken into account for afforestation investments.

In the present study, three seedling types (bare rooted, ENSO and containerized) were tested for survival and growth rates of cedar afforestation at two different sites (Yelten and Urkutlu) for past 13 years. Moreover, seedling and establishment costs were analysed in details by seedling type for each test site.

\section{Materials and Methods}

One-year-old bare rooted, ENSO type and contain erized seedlings, which are commonly used by the Forest Service, were tested at 13 years. ENSO is a seedling type raised in plastic pot trays with different number of cells and different dimensions using peat growth medium. Pot trays with $9 \times 5=45$ cells and each cell of dimension of $4 \times 5 \times 10 \mathrm{~cm}$ were used. These seedlings were initially grown in greenhouses in spring and early summer, after which the seedlings were acclimatized to open areas for the rest of the summer. Containerized seedlings were grown in cylinder shaped polyethylene bags with a diameter of $10 \mathrm{~cm}$ and height of $25 \mathrm{~cm}$. These dimensions are preferred for afforestation. The seeds were collected from natural forest stands in Antalya-Elmali provenance and all seedlings were grown under operational conditions with conventional nursery culture. Bare rooted and polyethylene container seedlings were produced in Egirdir Forest Nursery, while ENSO seedlings were grown in Denizli Forest Nursery.

Test sites were established in the winter (February) of 2003 prior to the growing season at two ecologically different sites that were Yelten and Urkutlu. Experimental sites were located in the area where Cedar was identified as one of the indicator tree species by Negiz et al. (2015).

The annual precipitation of study area was 673 and 382 $\mathrm{mm}$ and elevation of 1245 and $955 \mathrm{~m}$ soil was sandy-loam and loam. According to Walter diagrams, Yelten and Urkutlu sites suffered from water deficiency during May-October and JuneSeptember, respectively.

Experimental design : Randomized complete block planting was carried out at each site and the seedlings were planted at a spacing of $2.0 \mathrm{~m} \times 3.0 \mathrm{~m}$. Each test site contained 6 blocks (replications) with each block undergoing three seedling type treatments. Each seedling type treatment within each block was represented by 30 observation trees, which were applied as three line parcels ( 3 parcels $x 10$ observations). Each parcel containing 10 observations was randomly distributed on each block and 
plantation was applied in the way usually performed by Forest Service.

Height $(\mathrm{cm})$ was measured every year in the last seven years starting from 7 to 13 years of age. Diameter at ground level $\left[\mathrm{d}_{0}(\mathrm{~mm})\right]$ was also measured at 13 years. The data of last 13 year was collected and used for statistical analyses.

Analysis of variance (ANOVA) was performed to investigate the effect of seedling type on survival rates, height and $\mathrm{d}_{0}$ growth rate by General Linear Models (GLM) in SPSS statistical software v. 22.0 (SPSS, 2014). Duncan's multiple range test was applied to test the differences between the treatments when they were found to be significantly $(P<0.05)$ different in the main model of ANOVA. Survival rate data were transformed using arc-sin transformer before statistical analyses.

Economic evaluations were conducted on the basis of the calculation of the seedling cost and afforestation investment cost by seedling types, taking account of the unit price of nursery and afforestation activities of the General Directorate of Forestry (GDF). Costs were calculated considering the current components of seedling production activities and afforestation investment. Afforestation investment costs were based mainly on the following components of activities: ground clearance, soil cultivation, planting, maintenance, protection and fencing, transportation of seedlings and seedling cost. Costs were calculated in US\$ according to the conversion rate of 1 US\$ = 2.127 Turkish Lira effective on $15^{\text {th }}$ July 2014.

\section{Results and Discussion}

Statistical analyses showed that there were differences at $P<0.05$ level between the survival rates of the seedling types at both sites for the last 13 years. As shown from the Duncan's multiple range test results in the Table 1 , the survival rates for bare rooted, ENSO and containerized seedlings were 81\%, 73\% 91\% at Yelten and 94\%, 98\%, 97\% at Urkutlu site, respectively. Containerized seedlings had significantly higher survival rates than bare rooted seedlings at both the sites than ENSO seedlings in Yeltensite, where precipitation was less than the precipitation in Urkutlu.

The survival rates found in this study are consistent with the previous studies carried due to the fact that covering roots, container and growth medium provide a more suitable environment for seedling roots and help to overcome the summer drought and competing vegetation, especially in the first two years after planting (Mcdonald, 1991; Barnett and McGilvray, 1993; Wilson et al., 2007; Li et al., 2013). Grossnickle et al. (1987) measured greater new root development in containerized seedlings compared to bare rooted seedlings after field planting of jack pine.

Texas A\&M Forest Service (TFS) also evaluated the advantages and disadvantages of containerized and barerooted seedlings. They underlined that the advantages of containerized seedlings mainly included production at any time of the year, use of limited number of seeds, higher growth performance, higher survival rates and extended planting season. Consequently, they suggested the use of containerized seedlings despite of their high cost, arguing that some of the costs could be compensated by higher survival rate (TFS, 2015).

Water availability (water content of soil and root hydraulic conductivity) is one of the most important variables that contribute to the successful establishment and growth of seedlings (Burdett, 1990; Grossnickle, 2005; Pinto et al., 2011;Nath et al., 2016). In this context, rainfall in the months after planting is important for survival rates. In our study area, precipitation was higher than the long-term average during those months just after planting at all sites. GDM (2015) records showed that monthly precipitation for March, April, May and June 2003 for Korkuteli meteorological station close to Yelten was $89,63,76$ and $74 \mathrm{~mm}$, while the longterm average for the same months were $38,43,37$ and $25 \mathrm{~mm}$, respectively. It was $65,246,65$ and $20 \mathrm{~mm}$ for Burdur station close to Urkutlu while long-term averages were $45,46,44$ and $28 \mathrm{~mm}$ for the same months, respectively. This implies that survival rates would have been lower than the ones indicated above if

Table 1 : Effect of seedling type on survival, height and ground diameter at 13 years

\begin{tabular}{lllll}
\hline & & Survival $(\%)$ & Height $(\mathrm{cm})$ & Ground diameter $(\mathrm{mm})$ \\
\cline { 3 - 5 } & & \multicolumn{3}{c}{ ANOVA sig. } \\
\cline { 3 - 5 } Site & Seedling type & $\boldsymbol{P}<\mathbf{0 . 0 0 5}$ & $\boldsymbol{p}<0.001$ & $\boldsymbol{p}<0.001$ \\
\hline \multirow{2}{*}{ Yelten } & Bare rooted & $81.1 \mathrm{a}$ & $132.4 \mathrm{a}$ & $29.4 \mathrm{a}$ \\
& ENSO & $73.4 \mathrm{a}$ & $121.9 \mathrm{a}$ & $27.1 \mathrm{a}$ \\
& Containerized & $91.2 \mathrm{~b}$ & $170.4 \mathrm{~b}$ & $38.3 \mathrm{~b}$ \\
& Brkutlu & $93.9 \mathrm{a}$ & $212.0 \mathrm{a}$ & $47.2 \mathrm{a}$ \\
& Bare rooted & $98.8 \mathrm{ab}$ & $205.3 \mathrm{a}$ & $46.7 \mathrm{a}$ \\
& ENSO & $97.2 \mathrm{~b}$ & $249.1 \mathrm{~b}$ & $57.5 \mathrm{~b}$ \\
\hline
\end{tabular}

values with the same letter are not significantly different 

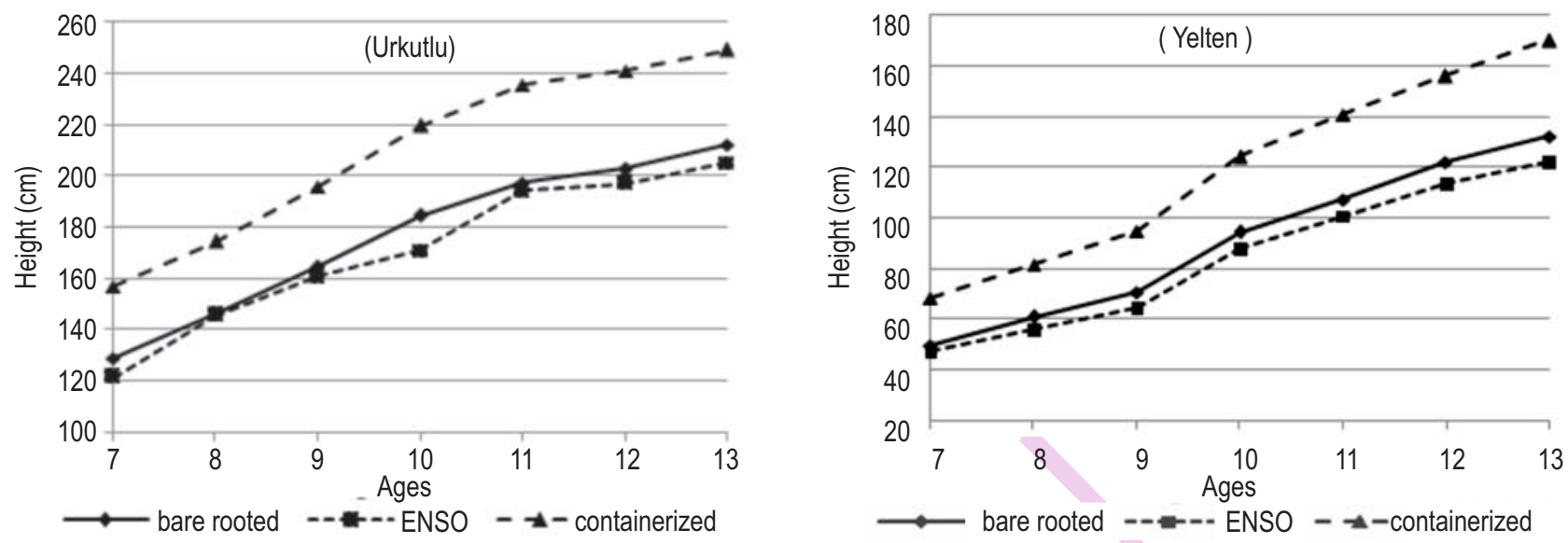

Fig. 1 : Height growth of seedling types of last seven years at experimental sites

Table 2 : Afforestation establishment cost per hectare by seedling types for two experimental sites

\begin{tabular}{|c|c|c|c|c|c|c|}
\hline \multirow[t]{3}{*}{ Activities } & \multicolumn{5}{|c|}{ Cost(US\$ ha $\left.{ }^{-1}\right)$} & \multirow[b]{3}{*}{ Containerized } \\
\hline & \multicolumn{2}{|c|}{ Yelten site } & & \multicolumn{2}{|c|}{ Urkutlu site } & \\
\hline & Bare rooted & ENSO & Containerized & Bare rooted & ENSO & \\
\hline Service road & 148.74 & 148.74 & 148.74 & 79.36 & 79.36 & 79.36 \\
\hline \multicolumn{7}{|l|}{ Site preparation } \\
\hline Ground clearance & 369.10 & 369.10 & 369.10 & 293.13 & 293.13 & 293.13 \\
\hline Soil cultivation (by tractor) & 332.79 & 332.79 & 332.79 & 286.08 & 286.08 & 286.08 \\
\hline Planting & 428.27 & 335.74 & 699.92 & 428.27 & 355.74 & 699.92 \\
\hline \multicolumn{7}{|l|}{ Maintenance (two years) } \\
\hline Replacementplanting & 92.32 & 115.23 & 65.50 & 36.93 & 7.638 & 25.19 \\
\hline Weed and shoot control & 463.11 & 463.11 & 463.11 & 463.11 & 463.11 & 463.11 \\
\hline Fencing & 345.04 & 345.04 & 345.04 & 345.04 & 345.04 & 345.04 \\
\hline Seedling transfer & 22.57 & 37.61 & 56.42 & 22.57 & 37.61 & 56.42 \\
\hline Seedling cost & 74.81 & 279.11 & 341.86 & 74.81 & 279.11 & 341.86 \\
\hline Total & 2276.77 & 2446.49 & 2822.49 & 2029.30 & 2146.87 & 2590.12 \\
\hline
\end{tabular}

precipitation had been identical to the long-term mean values and the differences between the seedling types would have been clearer.

Results revealed significant differences at $P<0.01$ level between the total height growth of the seedling types in favour of the containerized seedlings at both the sites and the total height of the containerized seedling type was higher than that of the other types both the sites (Table 1). The mean height of the containerized seedlings was $28 \%$ and $39 \%$ greater than those of the bare rooted and ENSO seedling types, respectively, in Yelten site (Fig. 1). These proportions were $17 \%$ and $21 \%$, respectively, at Urkutlu. Similar results were observed for diameter at both the sites.

Ortel (1995) reported similar findings in Pinus brutia plantations. He compared height growth of bare rooted and containerized seedlings of last 25 years and found significantly higher values in favour of the containerized seedlings. Urgenc $(1990 ; 1998 a)$ compared the bare rooted and containerized seedling types and suggested that containerized seedlings could be used in arid and semi-arid areas, underlining higher survival rates and longer planting periods throughout the year. Similarly, Ayan and Bahadir (1995) suggested the use of containerized seedlings rather than bare rooted seedlings for successful afforestation, especially in areas where ecological conditions were unfavourable. Indeed, during initial years of afforestation, larger seedlings can compete and protect themselves from weedy vegetation (Cicek et al., 2010). Pinto et al. (2011) underlined the advantageous of containerized seedlings providing longer planting season and higher survival rates for reforestation and restoration projects with unique planting conditions like dry, extremely rocky with little topsoil.

Another result of our study was that even though ENSO type seedlings were a kind of containerized seedling, their growth 
rate was significantly lower than that of the polyethylene containerized seedlings. This might be because of their different growth media and depth and volume of the containers. ENSO type seedlings had peat growth medium while polyethylene containers had a mixture of soil and humus. ENSO trays also had smaller cell width and depth, resulting in about a 10 fold difference in container volumes $\left(200 \mathrm{~cm}^{3}\right.$ vs $\left.1962 \mathrm{~cm}^{3}\right)$. Chirino et al. (2008) found higher above-ground and below-ground biomass of the seedlings cultivated in the containers that had a higher volume.

The economic evaluation was performed on the basis of the data gathered in this study. In this framework, seedling costs and afforestation investment cost per hectare with sub components was calculated (Table2). Cost per seedling was calculated as 0.045 US\$, 0.167 US\$ and 0.205 US\$ for bare rooted seedlings, ENSO and containerized seedling types, respectively. Seedling costs per hectare were also calculated considering that 1666 seedlings would be planted for one hectare ( $3 \times 2 \mathrm{~m}$ spacing $)$.

Afforestation investment cost per hectare was calculated as 2276.76 US\$, 2446.49 US \$ and 2822.49 US \$ for bare rooted stock, ENSO and containerized seedlings at Yelten. These costs were calculated as 2029.30 US $\$, 2146.87$ US $\$$ and 2590.12 US\$, respectively, at Urkutlu site (Table 2).

Afforestation investment cost of the containerized seedlings were found to be $23.9 \%$ and $15.4 \%$ higher than those of the bare rooted seedlings and ENSO types, at Yelten. These amounts were calculated as $27.6 \%$ and $20.6 \%$, respectively, at Urkutlu site. As for the rate of the seedling costs in the total afforestation establishment costs, they varied depending on the seedling type but did not exceed 13\% (for bare rooted, ENSO and containerized seedlings; $3.3 \%, 11.4 \%$ and $13.1 \%$ at Yelten site and $3.7 \%, 13.0 \%$ and $13.2 \%$ at Urkutlu, respectively). In the light of these rates, we underline that the containerized seedling types have superior growth performance. Therefore, at the end of the rotation period, plantations with containerized seedlings may easily tolerate the seedling cost differences.

Based on the evaluation of survival rate and total height growth of seedling of last 13 years, it can be concluded that containerized seedling type has advantage for a successful afforestation even if $15.4 \%-27.6 \%$ more investment cost in calculated for it, compared to the bare rooted and ENSO seedling types.

\section{Acknowledgments}

This research was funded by Turkish General Directorate of Forestry. The authors are grateful to Dr. Nevzat GURLEVIK from Suleyman Demirel University for his review and suggestions on the earlier version of the manuscript and to Steven SPEED from England, project officer at Office National des Forêts (ONF,
Paris, Fr.) for reviewing the English language of the text.

\section{References}

Ayan, S. and C. Bahadir: ENSO type seedling productions and its comparison with conventional seedlings. In: Proceedings of $\mathrm{I}$. International Bleak Sea Forestry Congress, Karadeniz Technical University, Trabzon, pp.126-133(1995).

Barnett, J.P. and J.M. McGilvray: Performance of container and bare-root loblolly pine seedlings on Bottom lands in South Carolina, South. J. Appl. For., 17, 80-83 (1993).

Boydak, M., H.F. Bozkus and C.U. Alptekin: Sylvicultural evaluations of Cedar (Cedruslibani A. Rich.) plantations made out of its natural distribution areas in Turkey. In: Proceedings of International Cedar Symposium, Forest Research Institute Publication, Ankara, Turkey, pp.180-192 (1990).

Boydak, M. and M. Calikoglu: Biology and Silvi culture of Lebanon Cedar (Cedruslibani A. Rich.). "The Foundation for Supporting the Mission of Forestry Development and Combating Forest Fires", Ankara: Ogem-Vak Press, pp. 224 (2008).

Burdett, A.N.: Physiological processes in plantation establishment and the development of specifications for forest planting stock. Can. J. For. Res., 20, 415-427 (1990).

Chirino, E., A. Vilagrosa, E.I. Hernandez, A. Matos and V.R. Vallejo: Effects of a deep container on morpho-functional characteristics and root colonization in Quercus suber L. seedlings for reforestation in Mediterranean climate. For. Ecol. Man., 256, 779-785 (2008).

Cicek, E., F. Yilmaz, F. Tilki and N. Cicek: Effects of spacing and postplanting treatments on survival and growth of Fraxinus angustifolia seedlings, J. Environ. Biol., 31, 515-519 (2010)

Erkan, N.: Growth performance of Cedar and Black pine in some plantations made outside of their natural distribution areas. In: Proceeding of Workshop on Plantations and Erosion Control Works in Arid and Semiarid Areas in Turkey. Urgup, Turkey, pp. 144-156 (2006).

GDF: Forests in Turkey. Published by General Directorate of Forestry, Ankara, No: 85 (available at: http://www.ogm.gov.tr/ekutuphane/ Yayinlar/Orman\%20Varlığımız.pdf), (9 March 2016).

GDM, 2015: Meteorological data base. General Directorate of Meteorology, Ankara, "http://www.mgm.gov.trl", (accessed in March 2016) (2012).

Grossnickle, S.C. and T.J. Blake: Comparison of water relation patterns for newly planted bare-root and container jack pine and black spruce seedlings on boreal cut-over sites. New For., 1, 101-116 (1987).

Grossnickle, S.C.: Importance of root growth in overcoming planting stress. New Forests, 30, 273-294 (2005).

Hizal, A., A. Ekizoglu, K. Sengonul, O. Karaoz, M. Hasdemir, A. Ertas and Y. Serengil: Evaluations of plantations and erosion control work in Kapadokya area. In: Proceeding of Workshop on plantations and erosion control works in arid and semiarid areas in Turkey. Urgup, Turkey, pp. 144-156 (2006).

Kucukkaya, I.:Afforestation in the arid and semiarid areas in Turkey. In: Proceedings of Symposium on combatting with decertification. Corum, Turkey, pp. 17-18 (2010).

Li, G.L., Y. Zhu, Y. Liu, L. Jiang, W. Shi, J. Liu, J. Wang and Z. Cheng: Effect of nursery nitrogen application of bare-root Larix olgensis seedlings on growth, nitrogen uptake and initial field performance. 
J. Environ. Biol., 34, 79-85(2013)

Mcdonald, P.: Container seedlings outperform bare rootstock : Survival and growth after 10 years. New For., 5, 147-156 (1991).

Nath, S., A.J. Nath and A.K. Das: Vegetative and reproductive phenology of a floodplain tree species Barringtonia acutangula from North East India. J. Environ. Biol., 37, 215-220 (2016).

Negiz, M.G., Y. Eser, E. Kuzugudenli and K. Özkan: Indicator species of essential forest tree species in the Burdur District. J. Environ. Biol., 36, 107-111 (2015).

Ortel, E.: Growth comparison of stands developed by different sowing and planting methods. J. Fore., 1, 7-19 (1995).

Pinto, J.R., J.D. Marshall, R.K. Dumroese, A.S. Davis and D.R. Cobos: Establishment and growth of container seedlings for reforestation: A function of stocktype and edaphic conditions. For. Ecol. Man., 261,1876-1884 (2011).
SPSS Inc.: SPSS 22.0 Guide to Data Analysis. Published by Prentice Hall, Upper Saddle River, NJ, USA. pp. 637 (2014).

TFS: Reforestation: Bareroot and Container Pine Seedlings, TEXAS A\&M Forest Service, http://tfsweb.tamu.edu (accessed in 07 March 2016) (2015).

Urgenc, S.: Plantation and afforestation techniques. Istanbul Univ. Forestry Faculty press. No: 407, Istanbul (1990).

Urgenc, S.:Seedling cultivation technique of forest trees and ornamental trees, Forestry Faculty Press, No: 442, Istanbul, Turkey, (1998a).

Wilson, E.R., K.C. Vitols and A. Park: Root characteristics and growth potential of containerized and bare-root seedlings of red oak (Quercus rubra L.) in Ontario, Canada. New For., 34,163-176 (2007).

Yaltirik, F. and U. Akkemik: Natural gymnosperms of Turkey. Ministry of Environment and Forestry, General Directorate of Forestry, Ankara, Turkey, p. 214 (2011). 